\title{
Work values in a changing economic environment: the role of entrepreneurial capital
}

\author{
Inmaculada Jaén* \\ Dept. Applied Economics I. University of Seville (Spain) \\ Francisco Liñán \\ Dept. Applied Economics I. University of Seville (Spain)
}

\section{Acknowledgements:}

A previous version of this paper was presented at the IJM track at the Second International Conference of The International Network of Business and Management journals (INBAM), Valencia March 2012. We are grateful to the guest editors and other participants for their comments and suggestions, which have greatly improved the paper. This study is part of a wider research project financed by the Regional Government of Andalusia (Department of Innovation, Science and Enterprise, Project No. P08-SEJ-03542). For more information, please visit: http://institucional.us.es/vie.

\begin{abstract}
Purpose: The need for more flexible, dynamic and innovative firms is widely recognised nowadays. Entrepreneurial capital may contribute to a more entrepreneurial labour force with work values aligned to those needs, thus becoming one of the firm's strategic resources. But entrepreneurial capital is not evenly distributed between countries and regions. This paper aims to measure the importance of a region's cultural values in determining its level of entrepreneurial capital, and considers how this may affect the characteristics of the work force.

Design/methodology/approach: Schwartz's (2004) approach to measuring cultural values will be followed. Entrepreneurial intentions will be used as a proxy for entrepreneurship capital, following Ajzen's (1991) theory of planned behaviour. A representative sample of 2974 adults with higher education was used in the empirical analysis.

Findings: Results show that the region's culture indirectly influences the entrepreneurial capital of its members. People in some regions are more pro-entrepreneurial, showing higher start-up intentions, due to their cultural characteristics.

Practical implications: Results help explain why a larger share of the workforce in some regions presents work values facilitating flexibility, creativity and innovation. Similarly, they explain some of the difficulties faced when transferring human resource practices that have been successful in one branch, to new branches in regions with lower entrepreneurial capital.

Originality/value: The paper is novel in that it contributes to explaining why the majority of firms in some regions enjoy a more flexible and innovative labour force than those in less entrepreneurial regions.
\end{abstract}

Keywords: entrepreneurial capital, work values, cultural values, entrepreneurial intention, Spanish regions

Article Classification: Research paper

\footnotetext{
*Corresponding author: inmajaen@us.es

Author bios: I. Jaén is Lecturer in Statistics, and PhD Candidate at the University of Seville. She has participated as research assistant in the VIE Project. She has presented research works at different international entrepreneurship conferences.

F. Liñán is Associate Professor in Economics and Entrepreneurship at the University of Seville. He is the main researcher in the VIE project. He has participated in international research projects and is member of the PEER and ESU networks in entrepreneurship. He has published several articles in scientific journals and book chapters, and regularly reviews manuscripts for a number of academic journals
} 


\section{Introduction}

In recent decades, increasingly accelerated economic change has been taking place. In particular, the strong pace of technological development coincides with the advance of globalisation resulting from greater market liberalisation and the integration of former communist countries in the capitalist economy. This has substantially increased competition, uncertainty and the fragmentation of markets, promoting a growing need for the flexibility, innovation and adaptive capacity of existing firms (Carlsson, 1996; Carree et al., 2002).

These changing economic conditions explain some of the shifts from the established work environment and the traditional patterns of employment (Castrogiovanni et al., 2011). This turbulence in the external work environment of organisations has notably altered the characteristics and qualities needed in manpower. There is an increasing need for a globally-aware work force that is able not only to implement, but also to generate innovations and new projects within organisations (Huse et al., 2005).

In this sense, entrepreneurial activity is attracting increasing attention as a useful instrument (Dabic et al., 2011). Thus, corporate entrepreneurship has been proposed as one key instrument to promote flexibility and change in existing organisations (Zahra et al., 1999). Corporate entrepreneurship may be defined as the activities that an organisation undertakes to enhance its product and process innovations, risk-taking and pro-active response to environmental forces (Castrogiovanni et al., 2011).

So far, attention has been concentrated on the entrepreneurial behaviour of owners and/or top managers (Clargo and Tunstall, 2011). Most research has focused on the actions to be implemented to transform their organisations into more entrepreneurfriendly ventures, that may foster innovation, venturing and strategic renewal (Lee et al., 2011). However, very little attention has been paid to the cultural and social environment as a conditioner of the characteristics of the workforce and their entrepreneurial attitudes (Peris-Bonet et al., 2011).

In this vein, one of the key resources needed for an effective development and implementation of corporate entrepreneurship strategies is a labour force exhibiting a sufficiently high level of entrepreneurial attitudes (Castrogiovanni et al., 2011; Chandler et al., 2000). Therefore, from a resource-based theory of the firm (Barney, 1991; Lee et al., 2011), this pro-entrepreneurial labour force may be seen as a strategic resource (Castrogiovanni et al., 2011; Sanz-Valle et al., 1999), not only for each individual firm, but for the region as a whole.

A region's entrepreneurial capital may be a good reflection of that capacity of its workforce. Entrepreneurial capital has been defined as the society's capacity to generate entrepreneurial activity (Audretsch and Keilbach, 2005; Aggestam, 2012). This capacity will be reflected not only in the creation of new ventures, but also in the development of innovative behaviours within existing organisations. Entrepreneurial capital will imply that pro-activity, initiative and pro-entrepreneurial work-values are more generally widespread among the labour force in that region (Senik and Verdier, 2008; Audretsch and Keilbach, 2005). Therefore, higher entrepreneurial capital will result in improved capacity to adapt to the changing economic environment, both through the creation of new firms, and also as a result of a better-suited labour force in existing firms. 
However, entrepreneurial capital is not evenly distributed between countries and regions. Different levels of entrepreneurial activity and attitudes do exist (Davidsson and Wiklund, 1997; Frederking, 2004). A substantial portion of these differences have been attributed to culture (Davidsson, 1995). In this sense, it is argued that cultural beliefs and values prevailing in each society have a significant influence on the entrepreneurial behaviour of individuals in that society (Liñán and Chen, 2009; Liñán et al., 2011c). The societal value structure shaping culture may play a significant role in determining entrepreneurial capital. That is, the entrepreneurial intention of their members (Krueger, 2000; 2003; Davidsson, 1995).

Thus, the present study is novel in that it tries to shed light on some of the factors that explain the relative presence of pro-entrepreneurial attitudes in the regional or national labour force. It aims at better explaining geographical differences in the work values and adaptive capacity of the workforce. In particular, it analyses the relationship between cultural values and entrepreneurial capital (in the form of the individuals' entrepreneurial intention) in order to explain regional differences in the entrepreneurial attitudes of the labour force. This paper also stands out in the characteristics and representativeness of the population studied. Contrary to most previous research in this field, this study analyses a general sample of adults in the population, and not a specific subset of them (be it students, nascent entrepreneurs, etc.). Hence, a more comprehensive picture of the general attitudes of the labour force is obtained.

The results of this study will contribute to the literature on the resource-based approach to the firm. It will add some additional insights on the relative advantage of some firms derived from their locations (Lee et al., 2011), which grant them access to some strategic resources and capabilities. The regions or countries where entrepreneurial capital is higher will present a more flexible, adaptive and proentrepreneurial labour force. This should enormously facilitate the development of innovative human-resource practices within firms, and may help them improve performance. On the other hand, with regard to less entrepreneurial regions or countries, the results will also be useful to design and implement actions to compensate these relative weaknesses of the labour force -both on the part of entrepreneurs and managers, and also on the part of public decision-makers.

After this introduction, the next section presents the proposed theoretical model. In section three, the methodology used in the empirical analysis is described. Results are presented in section four. The paper ends with a discussion of these results and a conclusion section.

\section{Theoretical framework}

In this section, the concept of entrepreneurial capital is firstly considered, and special attention is paid to entrepreneurial intention as a proxy for it. Then, Schwartz's approach to cultural values is introduced. The model and hypotheses to be tested are derived from the interplay of both strands of the literature. 


\subsection{Entrepreneurial capital and intentions}

Entrepreneurship is considered one of the most important factors contributing to economic development and has numerous benefits for society. It drives innovation, creates jobs, develops human potential, and satisfies new customer demands (European Commission, 2003). The entrepreneurial capital of a society may be measured not only as the number of start-ups (Audretsch and Keilbach, 2005; Aggestam, 2012), but also as the level of the entrepreneurial potential (intention to start a venture) of its members (Krueger et al., 2000).

It is expected that higher entrepreneurial capital will result in a more flexible labour force (Castrogiovanni et al., 2011; Audretsch and Keilbach, 2005; Dabic et al., 2011). Therefore, the flexibility and innovativeness of human resources in both small and large firms may be affected by the local level of entrepreneurial capital. Those firms based in more entrepreneurial regions would benefit from a more flexible and innovative labour force. For companies, a more entrepreneurial labour force may contribute to reaping these benefits through means such as corporate entrepreneurship (Castrogiovanni et al., 2011; Zahra et al., 1999).

In the vast majority of territories, SMEs represent the largest share of total firms. In this sense, these smaller firms may benefit the most from a more pro-entrepreneurial labour force, since their possibilities to attract highly specialised manpower from abroad are limited. Owner-mangers themselves are part of the local population and may be affected by the overall level of entrepreneurial attitudes in the local environment. Thus, more pro-entrepreneurial owner-managers may become the best catalysts to promote the innovativeness, flexibility and competitiveness of their firms and, subsequently, of the local economy (Castrogiovanni et al., 2011; Carrier, 1994). As a consequence, firms wishing to develop an entrepreneurial manpower may find it easier if they are located in these more entrepreneurial areas. The existence of a more pro-entrepreneurial labour force may be a very relevant strategic resource for firms in these regions (Kyvik et al., 2012).

Entrepreneurial intention may be used as a proxy for entrepreneurship capital, since the entrepreneurial behaviour could be considered as a type of planned behaviour for which the intention models are ideally convenient (Krueger et al., 2000; Krueger and Carsrud, 1993). In this line, the entrepreneurial intention would be a previous and determinant element towards performing entrepreneurial behaviours (Kolvereid, 1996; Bird, 1988). Several models have been used to explain the entrepreneurial intention, although they have not been as influential as the Theory of Planned Behaviour (TPB, Krueger and Carsrud, 1993; van Gelderen et al., 2008; Liñán and Chen, 2009; Tkachev and Kolvereid, 1999; Krueger et al., 2000). Unlike other models, the TPB offers a coherent and generally applicable theoretical framework. This enables us to understand and predict entrepreneurial intentions by taking into account not only personal but also social factors (Krueger et al., 2000).

Three elements explain intention, according to the TPB. Firstly, the attitude towards behaviour within the TPB is defined as an individual's overall evaluation of the behaviour (Ajzen, 1991). This is determined by the total set of accessible behavioural beliefs linking the behaviour to various outcomes and other attributes. In addition, the 
strength of each belief is weighted by the evaluation of the outcomes (Ajzen, 1991). The second component of the TPB is the subjective norm, which is defined as the individual's perception of the social pressures to engage (or not to engage) in entrepreneurial behaviour (Ajzen, 1991). The subjective norm consists of two components: normative beliefs and the motivation to comply with these beliefs. The third TPB component, perceived behavioural control (PBC), refers to people's perceptions of their ability to perform that behaviour. This concept is, therefore, very similar to self-efficacy (or even the same, see Bandura, 1982). In fact, self-efficacy has replaced PBC in numerous studies (Krueger et al., 2000; Kolvereid and Isaksen, 2006; Moriano et al., 2007; van Gelderen et al., 2008), and a recent meta-analysis shows a strong and positive relationship with business creation and entrepreneurial success (Rauch and Frese, 2007).

According to this psychological theory, intention is affected by these three antecedents alone, and any other variable may influence it only to the extent that it modifies perceptions regarding these antecedents (Ajzen, 1991; 2001; 2002b). Therefore, attention should be devoted to culture to understand how this effect takes place.

\subsection{Cultural values}

The study of values can be done from a personal perspective (i.e., at the individual level) or a cultural perspective (from the society's level of analysis). Personal values represent the individual goals and motivations which serve as a guiding principle in life (Rokeach, 1973; Schwartz, 2004). Starting from personal-level values, researchers have moved their focus to consider the study of one culture or even cross-cultural comparative studies (Fischer, 2006). Several theories have been developed to address the concept and structure of cultural values (Hofstede, 2003; Schwartz, 1999; Triandis, 1995; Inglehart, 1997). While they differ in both their methodology and approach, they all share the same goal: determining a useful framework to make comparisons between cultures.

Values at the cultural level represent abstract, socially shared ideas about what is good and right and desirable in a society (Williams, 1968). Cultural values are inherent to the structure and functioning of social institutions (Schwartz and Ros, 1995). They are likely to influence behaviour, as shown in the literature (Verplanken and Holland, 2002; McGuire et al., 2006).

In this paper, Schwartz's theory will be followed. This considers cultural values as averaged individual values (Schwartz, 1994; 1999; 2004). This theory is based on a universal system of values that guide human behaviour. Specific cultural contexts make some of them prevail over others (Schwartz, 2006). This mechanism works through social institutions and their actions (through legislation, government directives, the education system, etc.), selecting and prioritising some values over the others. In this sense, people tend to carry out what they believe is socially appropriate behaviour (Bourdieu, 1991; Markus and Kitayama, 1991; Schwartz, 1994).

At the aggregate level, seven types of cultural values may be identified (Schwartz, 1994): Embeddedness, Intellectual Autonomy, Affective Autonomy, Hierarchy, 
Egalitarianism, Mastery and Harmony. They may be grouped into three bipolar dimensions (See Figure 1).

- Embeddedness vs. (intellectual and affective) Autonomy: This dimension covers the troubled relationship between the individual and the group. At the Embeddedness end, the person is seen as an entity that is included in the community (examples of values may be social order, respect for tradition, family security or wisdom). Meanwhile, at the other end, the person is an autonomous body that finds meaning in his/her own difference (to be curious, open-minded or creative are values within Intellectual Autonomy; pleasure, varied life or exciting life are Affective Autonomy values). Of course, the relative strength of Affective and Intellectual autonomies may make a difference at the cultural level (see Schwartz and Ros, 1995, for a comparison of western European countries). Many theorists associate individualism with the selfinterested pursuit of personal goals (Triandis, 1995). However, self-interest is equally present in both sides of the embeddedness-autonomy dimension (Schwartz, 2004).

- Hierarchy vs. Egalitarianism: The second societal problem is to guarantee responsible behaviour that preserves the social fabric. People must be induced to consider the welfare of others, to coordinate with them, and thereby manage their unavoidable interdependencies. This addresses the responsible, cooperative behaviour that will get societal tasks done, either by differentiating roles or by internalising commitment and voluntary cooperation (Schwartz, 1994). At the Hierarchy end of this dimension, the unequal distribution of power, roles and resources is considered legitimate (social values such as power, authority, humility, wealth). Meanwhile, at the Egalitarianism end, the members of society are considered as equal beings who share a commitment to cooperate with others and pursue the common good (social values such as justice, freedom, responsibility, honesty).

- Mastery vs. Harmony: This dimension helps solve the problems of the relations between people and nature. Those cultures which are heavily sided towards the Mastery pole are seeking personal gain through the exploitation and domination of nature (ambitious, successful, competitive, risk-taker). On the Harmony side are placed, on the other hand, cultures that seek individuals fitting in harmoniously with nature (unity with nature, protecting the environment and so on).

\section{Insert Figure 1 about here}

These cultural value orientations also present a framework of cultural compatibility (Schwartz, 1994; 1999), since some of them share common basic assumptions. For instance, hierarchy and embeddedness are positively related, sharing the idea that personal roles and obligations to collectivities are more important than individual ideas and aspirations. The same is true about egalitarianism and intellectual autonomy. They share the idea of a social actor who takes on individual responsibility and makes personal decisions based on their understanding of situations. In practice, high egalitarianism and intellectual autonomy are usually found together, as in western Europe (Schwartz and Ros, 1995).

The shared and opposing assumptions inherent in cultural values yield a coherent circular structure of relations between them (Schwartz, 1999). As shown in Figure 1, the structure reflects the cultural orientations that are compatible (adjacent in the circle) or 
incompatible (distant around the circle). This conception of cultural dimensions as forming an integrated system, derived from a priori theorising, distinguishes this approach from others. Hofstede (2003) conceptualised his dimensions as independent, while Inglehart (1997) empirically derived two broad cultural components.

\subsection{Research model and hypotheses}

Since culture is a set of shared values (Schwartz, 1999), it is likely to influence patterns of thinking and acting. As Hofstede (2003) argues, culture is the collective programming of the mind, distinguishing the members of one group or category of people from others. Therefore, people's perceptions and intentions are at least partially determined by the cultural norms they share (Hechavarria and Reynolds, 2009).

In the case of entrepreneurship, researchers have argued that a country's culture, values, beliefs and norms affect the entrepreneurial orientation of its residents (Busenitz and Lau, 1996; Knight, 1997; Tiessen, 1997; Hechavarria and Reynolds, 2009). In particular, individualistic values such as competition, enjoyment, pleasure, an exciting and varied life, self-reliance, social recognition, imagination and broad-mindedness are related to entrepreneurial intention and activity (Morris and Schindehutte, 2005; Wdowiak et al., 2007). In contrast, where values relevant to economic innovation and personal success may conflict with traditional cultural values, entrepreneurship may not be approved of by society (Morris and Schindehutte, 2005) and the hostile environment may hamper entrepreneurial intentions (Wdowiak et al., 2007). This result has been confirmed by Noseleit (2010) for the self-employed.

According to Schwartz (1994; 1999; 2008), autonomy and egalitarianism are usually associated together and close to Hofstede's (2003) dimension of individualism. Similarly, harmony tends also to be prevalent in continental Europe (where Spain is located), and associated with autonomy and egalitarianism (Schwartz and Ros, 1995). For this reason, one should expect that a prevalence of these three values (positive score of the corresponding dimension) will be linked with higher entrepreneurial intentions (Hechavarria and Reynolds, 2009).

Since the TPB model establishes that intention is explained by its three antecedents alone (Ajzen, 1991), it is expected that the influence of cultural values on entrepreneurial intention should be indirect, through its effect on the motivational antecedents of intention. Figure 2 presents the research model to be tested in the empirical analysis. Thus, based on this theory, the present study aims at testing the following hypotheses:

\section{Insert Figure 2 about here}

H1: The predominant cultural value-dimensions in the region are related to the entrepreneurial intention (EI) of its people as follows:

H1.a: Embeddedness-Autonomy is positively related to EI

H1.b: Hierarchy-Egalitarianism is positively related to EI

H1.c: Mastery-Harmony is positively related to EI 
H2: The relationship between the cultural value-dimensions in the region and EI is fully mediated by its motivational antecedents as follows:

H2.a: The relationship is mediated by the entrepreneurial attitude

H2.b: The relationship is mediated by the subjective norm

H2.c: The relationship is mediated by the perceived behavioural control

\section{Methodology}

The empirical study has been conducted on a sample of the general adult population, all of them with higher education, obtained as part of the VIE project. A questionnaire was developed to study the values, motivations and intentions of potential entrepreneurs. A network of 15 university's alumni associations contributed to a final sample of 3223 alumni (mean age 28.08; $S D=4.98$ ). Table 1 shows some of the main sample characteristics. The vast majority of responses (2974, 92.3\% of the total sample) corresponded to seven of the 17 regions into which Spain is divided. Therefore, these seven regions are to be studied, and the remaining cases disregarded (see Table 2).

\section{Insert Table 1 about here}

Participation in the study was voluntary. All questionnaires were completed anonymously to ensure confidentiality. Questionnaires were completed over the Internet, as part of the development of the VIE Project. The VIE project attempts to assess the influence of personal and cultural values, along with socioeconomic variables, in the formation of entrepreneurial attitudes and intentions. Data collection took place from February to October 2010.

\subsection{Measurement Instrument}

The VIE instrument includes a TPB questionnaire and Schwartz's Portrait Value Questionnaire (PVQ, Schwartz et al., 2001; Schwartz, 2008). The former measures entrepreneurial intention and its antecedents, whereas the latter measures value priorities. The TPB questionnaire is comprised of four subscales: attitude towards entrepreneurship, subjective norms, PBC, and entrepreneurial intention. Unlike other questionnaires used in the field (Krueger et al., 2000; Liñán \& Chen, 2009), EIQ follows Ajzen's (2002a) methodological recommendations on how to construct a TPB questionnaire using composite measures of attitudes and subjective norm. All items in the questionnaire were measured on a 7-point Likert-type scale (from 0 to 6). The TPB questionnaire is included in the Appendix.

The dependent variable, entrepreneurial intention, was measured using a five-item scale in which each item assesses the perceived likelihood of an individual to choose an entrepreneurial career. Higher scores reflect stronger entrepreneurial intentions. To prevent acquiescence bias, the third item (f3) was reversed (see Appendix).

The independent variables include TPB antecedents. Attitude towards entrepreneurship was measured through two sets of six items, assessing the expected outcomes of an entrepreneurial career and the desirability of these outcomes, 
respectively. Following Ajzen (2002a), outcome expectations were multiplied by their desirability and then divided by six to obtain scale average scores. Subjective norms were measured with two sets consisting of three items each. These measure how the respondents think significant others (e.g. parents) would view their entrepreneurial career choice, as well as their motivation to comply with these reference people. These two sets were multiplied and then divided by three. Perceived behavioural control has been measured through a six-item scale, combining elements of self-efficacy and controllability, in line with the theory (Ajzen, 1991; 2002b) and previous research on entrepreneurial intentions (Krueger et al., 2000; Kolvereid and Isaksen, 2006; Moriano et al., 2007; van Gelderen et al., 2008). In all cases, higher scores indicate a higher (more positive) level of the variable.

Personal values have been measured through Schwartz's PVQ (Schwartz, 2006; 2008; Schwartz et al., 2001). This includes 40 statements describing different profiles of people. Respondents are asked to state the extent to which they identify themselves with these profiles. The average for each region has been computed for the 40 value items. These regional-level scores were then averaged into seven cultural values following Schwartz (2004) and Schwartz and Ros (1995) [I]. Finally, the seven cultural values were grouped again into three bipolar cultural dimensions, by subtracting the score in the first cultural value from the score in the second: Embeddedness-Autonomy (Autonomy being the average of intellectual and affective autonomy), HierarchyEgalitarianism and Mastery-Harmony. In all three cases, a negative value represents the predominance of the first element (embeddedness, hierarchy or mastery), whereas a positive value reflects the predominance of the second element (autonomy, egalitarianism or harmony). Table 2 presents the average scores for each of the seven regions studied.

\section{Insert Table 2 about here}

As may be seen from Table 2, in the seven Spanish regions autonomy, egalitarianism and harmony prevail over the opposite orientations (embeddedness, hierarcy and mastery, respectively). This is expected of any developed country in continental Europe (Schwartz and Ros, 1995; Schwartz, 2004). In English-speaking countries, in turn, mastery is found to prevail over harmony.

Nevertheless, the cultural differences between the Spanish regions are noticeable, despite belonging to the same country. As a reference, comparable data for European countries (excluding the English-speaking ones) from the SVS international database (Schwartz and Boehnke, 2004) are presented for each dimension: EmbeddednessAutonomy ranges from 0.218 (France) to 1.804 (Switzerland), with an average of 1.019; Hierarchy-Egalitarianism ranges from 1.492 (Greece) to 1.778 (Norway), with an average of 1.589; Mastery-Harmony ranges from 0.043 (Netherlands) to 0.566 (France), with an average of 0.246. The cross-regional differences in Spain are, therefore, quite as substantial as those between European countries.

Two culturally-differentiated areas can be identified (See Figure 3). The Mediterranean (Catalonia and Valencia) exhibits below average egalitarianism and harmony, while above average autonomy. In contrast, the north (Basque Country and Galicia) is relatively high on the former two dimensions, while lower on autonomy. Apart from these two clearly-differentiated areas, Castille-Leon is a relatively northern inland region, but is culturally very similar to Andalusia on these three dimensions 
(although their income level and many other social conditions differ widely). Finally, Madrid is also inland, but it is culturally closer to Catalonia in autonomy (above average) and harmony (below average), but higher than this region in egalitarianism. Despite the income level of the Basque Country being even higher than those of Madrid and Catalonia, this region is clearly different from them in cultural values.

\section{Insert Figure 3 about here}

\subsection{Control variables}

The demographic and socioeconomic characteristics of individuals have been found to correlate with start-up behaviour. Nevertheless, the explanatory capacity of these variables have been very limited (Robinson et al., 1991). In this sense, age and gender are typical examples of demographic variables affecting entrepreneurship (Levesque and Minniti, 2006; Langowitz and Minniti, 2007). Similarly, people's age, gender, education, and other characteristics largely determine the life circumstances to which they are exposed. These include their socialisation and learning experiences, the social roles they play, the expectations and sanctions they encounter, and the abilities they develop. Thus, differences in background characteristics reflect varying life circumstances that affect value priorities (Schwartz, 2006).

Labour experience and, in particular, self-employment experience are very relevant sources of information, skill-development and knowledge that may be relevant in the start-up decision (Cooper et al., 1994; Dahlqvist et al., 2000). Vicarious learning (Bandura, 1997) may also be important when an entrepreneurial role model is available (Matthews and Moser, 1996; Scherer et al., 1991). Therefore, a number of control variables have been considered in the analysis: age, gender, labour experience, selfemployment experience, family role model and socioeconomic level.

Additionally, the development level of each region may affect cultural dimensions and may also exert an influence on the entrepreneurial attitudes of its members. A number of works have found a relationship between economic development and entrepreneurship (van Stel et al., 2003; Verheul et al., 2002; Reynolds et al., 1994; Carree et al., 2002). In particular, GDP per capita is commonly used to account for economic development in both entrepreneurship (Minniti et al., 2006; Lee and Peterson, 2000) and cultural (Schwartz, 1999; 2004; Hofstede, 2003; Hofstede et al., 2004) studies. In this paper, the relative level of GDPpc, compared to the national average, has been taken as a proxy for the regional level of economic development (see Table 2).

Since all the regions studied belong to the same country, they share common institutional and macro-economic frameworks. This is useful to minimise and control for the influence of variables not considered in the analysis. Once income level is taken into account, the differences found between regions may be reasonably attributed to differing cultural values.

\section{Results}

Table 3 presents the results of the hierarchical linear regression models with the entrepreneurial intention as the dependent variable. Model 1 considers only demographic variables. Initially, age, age-squared and socioeconomic level were 
included, but strong multicollinearity was present, therefore, they were eliminated. Not surprisingly, males exhibit higher entrepreneurial intentions than females (Minniti and Nardone, 2007). Similarly, those with previous self-employment experience or a family role model tend to show higher intentions.

\section{Insert Table 3 about here}

As a second step (Model 2 in Table 3), the regional-level variables (three cultural dimensions and GDP per capita) were included in the analysis. Again, multicollinearity was present. To solve this problem, following practice (Pinillos and Reyes, 2011; Venkatraman, 1989), the variables were centred (change of origin, with zero mean). This transformation completely solved the problem. As may be seen, there is a significant influence of the embeddedness/autonomy dimension on entrepreneurial intention, and the effect of income is negative and highly significant. Therefore, hypothesis H1a is supported, while hypotheses H1b and H1c are not.

Nevertheless, when TPB antecedents are included (Model 3), the coefficient for autonomy becomes non-significant. This would suggest that the effect of culture on intention is mediated by the intention antecedents (as hypothesis $\mathrm{H} 2$ stated). Additionally, as the TPB predicts, all three motivational antecedents significantly contribute to explaining entrepreneurial intentions, with the expected signs. Besides, as may be observed, they channel part of the effect of the demographic variables (their $\beta$ coefficients are lower than in Model 1). Regarding GDP per capita, a marginallysignificant negative effect remains, meaning that people in higher-income regions tend to present slightly lower entrepreneurial intentions than those in relatively-poorer regions.

To test hypothesis H2, new linear regression models were run, with the TPB antecedents as the dependent variables (see Table 4). Models A1 (explaining attitude to entrepreneurship), S1 (explaining subjective norm) and P1 (explaining perceived behavioural control) include only demographic variables. Again, age and age-squared had to be eliminated from the analysis due to multicollinearity problems.

In all three cases, the explained variance is much lower than in the case of intention. Still, both a family role model and a relatively high socioeconomic level exert a positive and significant influence over the three antecedents. Experience, either as employee or self-employed, also helps to increase perceived behavioural control. In turn, with regard to attitude towards entrepreneurship, only self-employment experience is significant. Finally, males feel that they are more able to become entrepreneurs than females.

\section{Insert Table 4 about here}

Model A2 includes cultural and income variables to explain the attitude towards entrepreneurship. As may be seen, people in regions where autonomy and/or harmony are relatively prioritised tend to present a more positive attitude. This gives support to hypothesis H2a. In contrast, but in line with results in Table 3, people in relativelyricher regions have a less positive attitude towards entrepreneurship. In Model S2, again, cultural variables at the regional level do exert a significant influence on the individuals' subjective norm, supporting hypothesis H2b. Finally, in Model P2, both cultural variables (embeddedness/autonomy and mastery/harmony dimensions are positively related) and income (negatively related) contribute to explaining the 
individuals' level of perceived behavioural control. Thus, support is found for hypothesis H2c. Therefore, it may be concluded that hypothesis H2 is supported. In particular, the embeddedness/autonomy and mastery/harmony dimensions are consistently related to the three antecedents of intention, while the hierarchy/egalitarianism cultural dimension has shown a very limited relation to the antecedents of entrepreneurial intentions (only marginally to attitude towards entrepreneurship).

\section{Discussion}

The results from the empirical analysis have been considerably satisfactory, since the hypotheses formulated found considerable support. From them, it may be claimed that a region's cultural values do affect the level of entrepreneurial intention of its inhabitants. This effect is, however, only indirect, through the TPB antecedents of intention. In particular, the labour force in regions where autonomy and harmony are prioritised will present a more entrepreneurial attitude that may contribute to making them more dynamic and innovative at work.

Cultural differences between countries have been found to affect human-resource management styles (Tixier, 1996). In this sense, the results from this paper may be very useful for researchers in human resources. According to them, regions or countries where entrepreneurial capital is higher will present a more flexible, adaptive and proentrepreneurial labour force. This should enormously facilitate the development of innovative human-resource practices within firms, and may help them improve performance.

The results may also help explain why the majority of companies in some regions (and countries) tend to present more flexible and innovative labour forces, when compared with those in other regions. There is a location advantage that goes beyond the existence of better infrastructure or market conditions. Similarly, the practice by some companies of moving headquarter managers to new subsidiaries in less entrepreneurial regions may be justified on this ground. It is expected that they will transfer the more pro-entrepreneurial culture of the headquarters into the new branch. In this way, the more dynamic work values in the entrepreneurial region could be transferred to branches/subsidiaries in less entrepreneurial areas. However, humanresource managers should be careful in this respect. As long as the majority of the job positions in the new subsidiary are filled with local people, human-resource practices implemented may fail to achieve success.

A number of contributions had already stressed the influence of culture on entrepreneurship (Davidsson and Wiklund, 1997; Frederking, 2004; Davidsson, 1995). Nevertheless, the mechanism through which this effect is exerted is far from clear. Firstly, it has been argued that a supportive culture would lead to social legitimation, making the entrepreneurial career more valued and socially recognised in that culture, thus creating a favourable institutional environment. This will cause more people to try to start their ventures, irrespective of their personal beliefs and attitudes (Etzioni, 1987). Secondly, it may be that a culture sharing more pro-entrepreneurial values and patterns of thinking leads to more individuals showing psychological traits and attitudes consistent with entrepreneurship (Krueger, 2000; 2003). Hence, more people will try to become entrepreneurs. 
The results from this paper give support to the psychological traits approach, since the people from regions prioritising autonomy (over embeddedness) and harmony (over mastery) do present a more positive attitude towards entrepreneurship, subjective norm and perceived behavioural control (PBC). And this, in turn, leads to a higher entrepreneurial intention, increasing regional entrepreneurial capital and resulting in more favourable work values. The same could be said about regions stressing harmony over mastery. Regarding egalitarianism, in turn, there are no differences in the attitudes and perceptions of the people. Overall, this would be in line with some previous evidence suggesting that a high perceived valuation of entrepreneurship in a society leads to more positive attitudes and intentions by individuals (Krueger and Carsrud, 1993; Liñán et al., 2011c) and, therefore, to higher entrepreneurial capital.

However, this should not be taken to imply that the social legitimation approach may be disregarded. As indicated by Schwartz (1994; 2006), the influence of culture on individuals' behaviour also works through social institutions and their actions (via legislation, government directives, the education system, etc.), selecting and prioritising some values over others (Liñán et al., 2011a). In this sense, people tend to carry out what they believe is socially appropriate behaviour, even if they do not share the underlying values (Bourdieu, 1991; Markus and Kitayama, 1991; Schwartz, 1994). That is, in regions with a more pro-entrepreneurial culture, even those individuals not sharing the predominant values will behave more entrepreneurially because this is socially expected of them.

Regarding the effect of income, the negative relationship found may be, at first sight, difficult to interpret. There is considerable evidence of the existence of a U-shaped relation between development and entrepreneurship (Bosma and Levie, 2010; Carree et al., 2002; Pinillos and Reyes, 2011). According to the income level, Spain should be placed at the upper right-hand side of the curve. However, within the regions, the effect of income is negative. One possible explanation would be that within a country (with a common market and institutional framework), a new U-shaped relationship is found, distinguishing between less-developed and more-developed areas of the country. Or it may simply be that the data collection was carried out during a recession and lessdeveloped regions exhibit higher unemployment. Thus, a stronger push factor and a lower opportunity cost could make more people in these lower-income regions intend to become entrepreneurs. The significant negative coefficient for income is in line with this argument. In this sense, respondents were asked whether they would start a venture out of necessity or to take advantage of an opportunity. In Andalusia, Galicia and Castille-Leon, the necessity motive was more prevalent than the national average.

The empirical analysis tends to support our hypotheses. However, the explained variance (R-squared) is low. Therefore, culture exerts a relatively weak effect, despite considerable regional differences in this respect. At least, this is the case within Spain, which, despite its cultural diversity, shares common institutional frameworks and markets. Additionally, some authors argue that cultural norms are more closely related to normatively-regulated behaviours, while individual values are more relevant in behaviours for which there are no clearly-established norms (Fischer, 2006). In this sense, there are no strong normatively-regulated behaviours about starting a venture in Spain, which may explain the relatively weak effect of culture.

Nevertheless, even a small difference in the percentage of people with high entrepreneurial intentions may have a significant effect on start-up rates and, through 
this, on perceived pro-entrepreneurial values in that region (Liñán et al., 2011b). Therefore, policy actions to promote certain cultural values in society (especially autonomy and harmony) would have positive implications for the dynamism, flexibility and innovativeness of the labour force. This would be a long-term action, but effects would spread across the whole set of local firms, both through the creation of new companies by entrepreneurial people, and through the hiring of more entrepreneurial workers in existing organisations.

\section{Conclusions}

Overall, it has been shown that the entrepreneurial capital of a region and the work values of the local labour force may be affected by the prevailing characteristics of its culture. The predominance of some cultural values leads to a higher level of entrepreneurial capital in the region, since individuals (both entrepreneurs and nonentrepreneurs) will exhibit higher entrepreneurial attitudes and intentions. This may be taken advantage of by local firms in the design and implementation of their humanresource practices, especially in the present period of rapidly-changing economic conditions.

For human-resource managers, one obvious implication that may be derived from this paper is the convenience of paying attention to the employees' personal values. In particular, practices to promote autonomy and, to some degree, harmony values could be especially helpful in developing the entrepreneurial attitudes of employees. In particular, recent trends seem to be emphasising the importance of self-direction and curiosity (intellectual autonomy) in many different job situations. At the same time, the end of the job-for-life is highlighting the importance of self-realisation and enjoyment when deciding a professional career path (affective autonomy). Finally, growing ecological concern (harmony) has led to the development of a whole new industry and has become a huge source of business opportunities. It seems that these values are becoming more and more useful in modern economies, and human-resource managers could consider them in the design and implementation of their strategies.

The applicability of these results to human-resource policies is yet to be fully tested. It may be argued, though, that multicultural teams should be built. In this way, the value priorities shared by the more entrepreneurial of them will compensate those of the less entrepreneurial workmates. In the case of Spain, it could be advisable for job positions to be filled by candidates from different regions, so that dynamic and innovative work values spread more easily throughout the firm.

The present study may suffer from a number of limitations that should be acknowledged. In particular, only seven regions were analysed. This caused a number of statistical problems (multicollinearity) that had to be solved by a zero-mean transformation. Although the results obtained are fully reliable and unbiased, they may still be sensitive to the specific regions analysed. Similarly, differing sample sizes in each region may also have an effect on the results. Therefore, the generalisability of these findings is yet to be confirmed. Future research should try to replicate these results in a wider set of regions, in different countries, and even in cross-country studies. A second limitation is related to the mechanism through which culture is transferred into higher entrepreneurial capital and more innovative and dynamic work values. Although the results seem to support the psychological traits approach, much research is needed 
to advance the knowledge in this field. This mechanism surely deserves closer attention. Finally, the socio-economic variables (such as access to credit and the increasing level of socio-political uncertainty) can also affect the individual's perception and entrepreneurship intention. The future development of this research should try to consider these effects.

\section{Notes}

[I] An Exploratory Factor Analysis was carried out to confirm that the items theoretically included in each cultural value were empirically supported by the data. Only 4 items were clearly placed in a different value (V9, V15, V34 and V38). However, since they also loaded secondarily on the expected factor, the theoretical distribution was followed. 


\section{Appendix. TPB Questionnaire}

A. For you, starting a new business (being an entrepreneur) would involve...

A1 Facing new challenges.

A2 Creating jobs for others.

A3 Being creative and innovative.

A4 Having a high income.

A5 Taking calculated risks.

A6 Being your own boss (independence).

\begin{tabular}{|c|c|c|c|c|c|c|}
\hline \multicolumn{2}{|c|}{$\begin{array}{l}\text { Totally } \\
\text { unlikely }\end{array}$} & \multicolumn{3}{|c|}{$\begin{array}{c}\text { Moderately } \\
\text { likely }\end{array}$} & \multicolumn{2}{|c|}{$\begin{array}{r}\text { Totally } \\
\text { likely }\end{array}$} \\
\hline 0 & 1 & 2 & 3 & 4 & 5 & 6 \\
\hline & 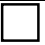 & & $L$ & - & $L^{\circ}$ & \\
\hline & $L$ & 5 & $\square$ & E & $\square$ & \\
\hline & $\square$ & 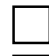 & $\square$ & 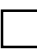 & $\square$ & \\
\hline$\square$ & $\square$ & $\square$ & $\square$ & 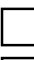 & $\square$ & $\square$ \\
\hline$\square$ & $\square$ & $\square$ & $\square$ & 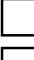 & $\square$ & $\square$ \\
\hline$\square$ & $\square$ & $\square$ & $\square$ & 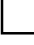 & $\square$ & $\square$ \\
\hline
\end{tabular}

B. Now please state to what extent these are desirable for you generally in your life...

\begin{tabular}{|c|c|c|c|c|c|c|}
\hline & & & ira & & & \\
\hline 0 & 1 & 2 & 3 & 4 & 5 & 6 \\
\hline 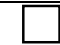 & & & & & & 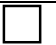 \\
\hline 5 & & & & & & $\square$ \\
\hline L & & & & & & $\square$ \\
\hline$\square$ & & L & & & & \begin{tabular}{|l}
$\square$ \\
\end{tabular} \\
\hline$\square$ & & $\square$ & & & & $\square$ \\
\hline$\square$ & & $\square$ & L & L & 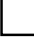 & $\square$ \\
\hline
\end{tabular}

E. Please indicate to what extent you would be able to effectively perform the following tasks:

E1 Defining your business idea and a new business strategy.

\begin{tabular}{|c|c|c|c|c|c|c|}
\hline \multicolumn{2}{|c|}{$\begin{array}{l}\text { Totally } \\
\text { ineffective }\end{array}$} & \multicolumn{3}{|c|}{$\begin{array}{l}\text { Moderately } \\
\text { effective }\end{array}$} & \multicolumn{2}{|c|}{$\begin{array}{l}\text { Fully } \\
\text { effective }\end{array}$} \\
\hline 0 & 1 & 2 & 3 & 4 & 5 & 6 \\
\hline$\square$ & $\square$ & $\square$ & $\bar{E}$ & $\bar{L}$ & $\square$ & 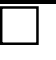 \\
\hline \begin{tabular}{|l} 
\\
\end{tabular} & $\square$ & 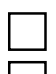 & Г & & & \\
\hline
\end{tabular}

E3 Negotiating and maintaining favourable relationships with potential investors and banks.

E4 Recognising opportunities in the market for new products and/or services.

E5 Interacting with key people to raise capital to create a new venture.

E6 Creating and putting into operation a new venture

C. Please, think now about your family and closer friends. To what extent would they agree if you decide to become an entrepreneur and start your own business?

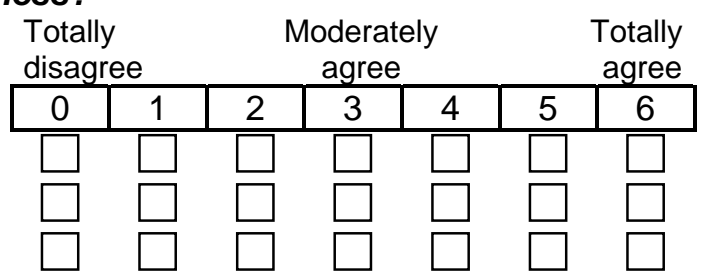




\section{D. ... and how do you value the opinion of these people in this regard? I think it is...}

D1 That of your immediate family (parents and siblings).

D2 That of your close friends.

D3 That of your colleagues of mates.

\begin{tabular}{|c|c|c|c|c|c|c|}
\hline \multicolumn{2}{|c|}{$\begin{array}{l}\text { Not at all } \\
\text { important }\end{array}$} & \multicolumn{3}{|c|}{$\begin{array}{c}\text { Moderately } \\
\text { important }\end{array}$} & \multicolumn{2}{|c|}{$\begin{array}{r}\text { Very } \\
\text { importan }\end{array}$} \\
\hline 0 & 1 & 2 & 3 & 2 & 5 & 6 \\
\hline L & & & & & & \\
\hline [ & & \begin{tabular}{|l} 
\\
\end{tabular} & \begin{tabular}{|l} 
\\
\end{tabular} & $L$ & $\square$ & $\square$ \\
\hline & L & $\square$ & \begin{tabular}{|l} 
\\
\end{tabular} & ¿ & $\square$ & \\
\hline
\end{tabular}

\section{F. Please state your level of intention with respect to the following statements:}

F1 It is very likely that I will start a venture someday

F2 I am willing to make any effort to become an entrepreneur

F3 I have serious doubts whether I will ever start a venture

F4 I am determined to start a business in the future

F5 Your professional goal is to be an entrepreneur

\section{References}

Aggestam, M. (2012), "Conceptualizing entrepreneurial capital in the context of institutional change", International Entrepreneurship and Management Journal, pp. 1-22.

Ajzen, I. (1991), "The Theory of Planned Behavior", Organizational Behavior and Human Decision Processes, Vol. 50, No. 2, pp. 179-211.

Ajzen, I. (2001), "Nature and operation of attitudes", Annual Review of Psychology, Vol. 52, pp. 27-58.

Ajzen, I. (2002a), "Constructing a TPB questionnaire: conceptual and methodological considerations", available at: http://www.people.umass.edu/aizen/ (accessed August 2011).

Ajzen, I. (2002b), "Perceived behavioral control, self-efficacy, locus of control, and the theory of planned behavior", Journal of Applied Social Psychology, Vol. 32, No. 4, pp. 665-683.

Audretsch, D. B. and Keilbach, M. (2005), "Entrepreneurship capital and regional growth", The Annals of Regional Science, Vol. 39, No. 3, pp. 457-469.

Bandura, A. (1982), "Self-efficacy mechanism in human agency", American Psychologist, Vol. 37, pp. 122-147.

Bandura, A. (1997), Self-efficacy: The exercise of control, Freeman, New York.

Barney, J. (1991), "Firm resources and sustained competitive advantage", Journal of Management, Vol. 17, No. 1, pp. 99-120.

Bird, B. (1988), "Implementing entrepreneurial ideas: the case for intention", Academy of Management Review, Vol. 13, pp. 442-453.

Bosma, N. and Levie, J. (2010), "Global Entrepreneurship Monitor: 2009 Executive Report", available at: http://www.gemconsortium.org/ (accessed October 2011).

Bourdieu, P. (1991), Language and Symbolic Power, Polity Press, Cambridge.

Busenitz, L. W. and Lau, C. M. (1996), "A cross-cultural cognitive model of new venture creation", Entrepreneurship Theory and Practice, Vol. 20, No. 4, pp. 25-39. 
Carlsson, B. (1996), "Small business, flexible technology, and industrial dynamics", in Admiraal, P. H. (Ed.) Small Business in the Modern Economy, Blackwell, Oxford, pp. 63125.

Carree, M. A., van Stel, A., Thurik, A. R. and Wennekers, A. R. M. (2002), "Economic development and business ownership: an analysis using data of 23 OECD countries in the period 1976-1996", Small Business Economics, Vol. 19, No. 3, pp. 271-290.

Carrier, C. (1994), "Intrapreneurship in large firms and SMEs: a comparative study", International Small Business Journal, Vol. 12, No. 3, pp. 54-62.

Castrogiovanni, G. J., Urbano, D. and Loras, J. (2011), "Linking corporate entrepreneurship and human resource management in SMEs", International Journal of Manpower, Vol. 32, No. 1, pp. 34-47.

Clargo, P. and Tunstall, R. (2011), "Leading an entrepreneurial workforce: development or decline?", Education and Training, Vol. 53, No. 8, pp. 762-783.

Cooper, A. C., Gimeno, J. and Woo, C. Y. (1994), "Initial Human and Financial Capital as Predictors of New Venture Performance", Journal of Business Venturing, Vol. 9, No. 5, pp. 371-395.

Chandler, G. N., Keller, C. and Lyon, D. W. (2000), "Unravelling the determinants and consequences of an innovation-suportive organizational culture", Entrepreneurship Theory and Practice, Vol. 25, No. 1, pp. 59-76.

Dabic, M., Ortiz-de-Urbina-Criado, M. and Romero-Martínez, A. M. (2011), "Human resource management in entrepreneurial firms: a literature review", International Journal of Manpower, Vol. 32, No. 1, pp. 14-33.

Dahlqvist, J., Davidsson, P. and Wiklund, J. (2000), "Initial conditions as predictors of new venture performance: A replication and extension of the Cooper et al. Study", Enterprise and Innovation Management Studies, Vol. 1, No. 1, pp. 1-17.

Davidsson, P. (1995), "Culture, structure and regional levels of entrepreneurship", Entrepreneurship and Regional Development, Vol. 7, No. 1, pp. 41-62.

Davidsson, P. and Wiklund, J. (1997), "Values, beliefs and regional variations in new firm formation rates", Journal of Economic Psychology, Vol. 18, No. 2-3, pp. 179-199.

Etzioni, A. (1987), "Entrepreneurship, adaptation and legitimation: a macro-behavioral perspective", Journal of Economic Behavior \& Organization, Vol. 8, No. 2, pp. 175-189.

European Commission (2003), Green Paper - Entrepreneurship in Europe, DG Enterprise. European Commission, Brussels.

Fischer, R. (2006), "Congruence and functions of personal and cultural values: Do my values reflect my culture's values?", Personal and Social Psychology Bulletin, Vol. 32, No. 11, pp. 1419-1431.

Frederking, L. C. (2004), "A cross-national study of culture, organization and entrepreneurship in three neighbourhoods", Entrepreneurship and Regional Development, Vol. 16, No. 3, pp. 197-215.

Hechavarria, D. M. and Reynolds, P. D. (2009), "Cultural norms \& business start-ups: the impact of national values on opportunity and necessity entrepreneurs", International Entrepreneurship and Management Journal, Vol. 5, No. 4, pp. 417-437.

Hofstede, G. (2003), Culture's consequences: comparing values, behaviors, institutions and organizations across nations, Sage Publications, Newbury Park.

Hofstede, G., Noorderhaven, N., Thurik, A. R., Uhlaner, L. M., Wennekers, A. R. M. and Wildeman, R. E. (2004), "Culture's role in entrepreneurship: self-employment out of dissatisfaction", in Brown, T. E. and Ulijn, J. M. (Eds.), Innovation, entrepreneurship and culture, Edward Elgar, Cheltenham, pp. 162-203.

Huse, M., Neubaum, D. O. and Gabrielsson, J. (2005), "Corporate innovation and competitive environment", International Entrepreneurship and Management Journal, Vol. 1, No. 3, pp. 313-333.

Inglehart, R. (1997), Modernization and Postmodernization, Princeton University Press, Princeton.

Knight, G. A. (1997), "Cross-cultural reliability and validity of a scale to measure firm entrepreneurial orientation", Journal of Business Venturing, Vol. 12, No. 3, pp. 213-225. 
Kolvereid, L. (1996), "Prediction of employment status choice intentions", Entrepreneurship Theory and Practice, Vol. 21, No. 1, pp. 47-57.

Kolvereid, L. and Isaksen, E. (2006), "New business start-up and subsequent entry into selfemployment", Journal of Business Venturing, Vol. 21, No. 6, pp. 866-885.

Krueger, N. F. (2000), "The cognitive infrastructure of opportunity emergence", Entrepreneurship Theory and Practice, Vol. 24, No. 3, pp. 5-23.

Krueger, N. F. (2003), "The cognitive psychology of entrepreneurship", in Acs, Z. J. and Audretsch, D. B. (Eds.), Handbook of entrepreneurship research: An interdisciplinary survey and introduction, Kluwer, London, pp. 105-140.

Krueger, N. F. and Carsrud, A. L. (1993), "Entrepreneurial intentions: applying the theory of planned behavior", Entrepreneurship and Regional Development, Vol. 5, No. 4, pp. 315330.

Krueger, N. F., Reilly, M. D. and Carsrud, A. L. (2000), "Competing models of entrepreneurial intentions", Journal of Business Venturing, Vol. 15, No. 5-6, pp. 411-432.

Kyvik, O., Zhang, Y. and Romero-Martínez, A. M. (2012), "Value dimensions and creativity: an international comparative study", International Journal of Manpower, Vol. 33, No. 4, pp. 349-366.

Langowitz, N. and Minniti, M. (2007), "The entrepreneurial propensity of women", Entrepreneurship Theory and Practice, Vol. 31, No. 3, pp. 341-364.

Lee, S. M., Peris-Ortiz, M. and Fernandez-Guerrero, R. (2011), "Corporate entrepreneurship and human resource management: theoretical background and a case study", International Journal of Manpower, Vol. 32, No. 1, pp. 48-67.

Lee, S. M. and Peterson, S. J. (2000), "Culture, entrepreneurial orientation, and global competitiveness", Journal of World Business, Vol. 35, No. 4, pp. 401-416.

Levesque, M. and Minniti, M. (2006), "The effect of aging on entrepreneurial behavior", Journal of Business Venturing, Vol. 21, No. 2, pp. 177-194.

Liñán, F. and Chen, Y. W. (2009), "Development and cross-cultural application of a specific instrument to measure entrepreneurial intentions", Entrepreneurship Theory and Practice, Vol. 33, No. 3, pp. 593-617.

Liñán, F., Rodríguez-Cohard, J. C. and Rueda, J. M. (2011a), "Factors affecting entrepreneurial intention levels: a role for education", International Entrepreneurship and Management Journal, Vol. 7, No. 2, pp. 195-218.

Liñán, F., Santos, F. J. and Fernández, J. (2011b), "The influence of perceptions on potential entrepreneurs", International Entrepreneurship and Management Journal, Vol. 7, No. 3, pp. 373-390.

Liñán, F., Urbano, D. and Guerrero, M. (2011c), "Regional variations in entrepreneurial cognitions: Start-up intentions of university students in Spain", Entrepreneurship and Regional Development, Vol. 23, No. 3\&4, pp. 187-215.

Markus, H. R. and Kitayama, S. (1991), "Culture and the self: Implications for cognition, emotion and motivation", Psychological Review, Vol. 98, pp. 224-253.

Matthews, C. H. and Moser, S. B. (1996), "A longitudinal investigation of the impact of family background and gender on interest in small firm ownership", Journal of Small Business Management, Vol. 34, No. 2, pp. 29-43.

McGuire, D., Garavan, T. N., Saha, S. K. and O'Donnell, D. (2006), "The impact of individual values on human resource decision-making by line managers", International Journal of Manpower, Vol. 27, No. 3, pp. 251-273.

Minniti, M., Bygrave, W. D. and Autio, E. (2006), GEM, Global Entrepreneurship Monitor, 2005 Executive Report, London Business School \& Babson College, London, U.K. \& Babson Park, MA.

Minniti, M. and Nardone, C. (2007), "Being in someone else's shoes: the role of gender in nascent entrepreneurship", Small Business Economics, Vol. 28, No. 2-3, pp. 223-238.

Moriano, J. A., Palací, F. J. and Morales, J. F. (2007), "The Psychosocial Profile of the University Entrepreneur", Psychology in Spain, Vol. 11, pp. 72-84. 
Morris, M. and Schindehutte, M. (2005), "Entrepreneurial values and the ethnic enterprise: An examination of six subcultures", Journal of Small Business Management, Vol. 43, No. 4, pp. 453-479.

Noseleit, F. (2010), "The entrepreneurial culture: guiding principles of the self-employed", in Freytag, A. and Thurik, A. R. (Eds.), Entrepreneurship and Culture, Springer, New York, pp. 41-54.

Peris-Bonet, F., Rueda-Armengot, C. and Galindo-Martin, M. A. (2011), "Entrepreneurial success and human resources", International Journal of Manpower, Vol. 32, No. 1, pp. 6880.

Pinillos, M.-J. and Reyes, L. (2011), "Relationship between individualist-collectivist culture and entrepreneurial activity: evidence from Global Entrepreneurship Monitor data", Small Business Economics, Vol. 37, No. 1, pp. 23-37.

Rauch, A. and Frese, M. (2007), "Let's put the person back into entrepreneurship research: A meta-analysis on the relationship between business owners' personality traits, business creation, and success", European Journal of Work and Organizational Psychology, Vol. 16, No. 4, pp. 353-385.

Reynolds, P. D., Storey, D. J. and Westhead, P. (1994), "Cross-national comparison of the variation in new firm rates", Regional Studies, Vol. 28, No. 4, pp. 443-456.

Robinson, P. B., Stimpson, D. V., Huefner, J. and Hunt, H. K. (1991), "An attitude approach to the prediction of entrepreneurship", Entrepreneurship Theory and Practice, Vol. 15, No. 4, pp. 13-31.

Rokeach, M. (1973), The nature of human values, Free Press, Nueva York.

Sanz-Valle, R., Sabater-Sanchez, R. and Aragon-Sanchez, A. (1999), "Human resource management and business strategy links: an empricial study", International Journal of Human Resource Management, Vol. 10, No. 4, pp. 655-671.

Scherer, R. F., Brodzinsky, J. D. and Wiebe, F. A. (1991), "Examining the relationship between personality and entrepreneurial career preference", Entrepreneurship and Regional Development, Vol. 3, pp. 195-206.

Schwartz, S. H. (1994), "Beyond Individualism-Collectivism: New cultural dimensions of values", in Kim, U., Triandis, H. C., Kagitçibasi, C., Choi, S. C. and Yoon, G. (Eds.), Individualism and collectivism. Theory, method, and applications, Sage, Thousand Oaks, CA, pp. 85-119.

Schwartz, S. H. (1999), "Cultural value differences: some implications for work", Applied Psychology: An International Review, Vol. 48, pp. 23-48.

Schwartz, S. H. (2004), "Mapping and Interpreting Cultural Differences around the World", in Vinken, H., Soeters, J. and Ester, P. (Eds.), Comparing Cultures, Dimensions of Culture in a Comparative Perspective, Brill, Leiden, The Netherlands.

Schwartz, S. H. (2006), "Les valeurs de base de la personne : théorie, mesures et applications", Revue Française De Sociologie, Vol. 47, No. 4, pp. 929-968.

Schwartz, S. H. (2008), Cultural value orientations: Nature and implications of national differences, Publishing House of SU HSE, Moscow.

Schwartz, S. H. and Boehnke, K. (2004), "Evaluating the structure of human values with confirmatory factor analysis", Journal of Research in Personality, Vol. 38, No. 3, pp. 230255.

Schwartz, S. H., Melech, G., Lehmann, A., Burgess, S. and Harris, M. (2001), "Extending the cross-cultural validity of the theory of basic human values with a different method of measurement", Journal of Cross-Cultural Psychology, Vol. 32, No. 5, pp. 519-542.

Schwartz, S. H. and Ros, M. (1995), "Values in the West: A theoretical and empirical challenge to the Individualism-Collectivism cultural dimension", World Psychology, Vol. 1, pp. 99122.

Senik, C. and Verdier, T. (2008), "Entrepreneurs, social networks and work values of ethnic minorities in France", International Journal of Manpower, Vol. 29, No. 7, pp. 610-629.

Tiessen, J. H. (1997), "Individualism, collectivism and entrepreneurship: A framework for international comparative research", Journal of Business Venturing, Vol. 12, No. 5, pp. 367384. 
Tixier, M. (1996), "Cultural adjustments required by expatriate managers working in the nordic countries", International Journal of Manpower, Vol. 17, No. 6, pp. 19-42.

Tkachev, A. and Kolvereid, L. (1999), "Self-employment intentions among Russian students", Entrepreneurship and Regional Development, Vol. 11, No. 3, pp. 269-280.

Triandis, H. C. (1995), Individualism \& collectivism, Westview, Boulder, CO; Oxford.

van Gelderen, M., Brand, M., van Praag, M., Bodewes, W., Poutsma, E. and van Gils, A. (2008), "Explaining entrepreneurial intentions by means of the theory of planned behaviour", Career Development International, Vol. 13, pp. 538-559.

van Stel, A., Wennekers, A. R. M., Thurik, A. R. and Reynolds, P. (2003), Explaining nascent entrepreneurship across countries. SCALES-paper N2003-01, EIM Business and Policy Research, Zoetermeer.

Venkatraman, N. (1989), "The concept of fit in strategy research: toward verbal and statistical correspondence", Academy of Management Review, Vol. 14, No. 3, pp. 423-444.

Verheul, I., Wennekers, A. R. M., Audretsch, D. B. and Thurik, A. R. (2002), "An eclectic theory of entrepreneurship", in Audretsch, D. B., Thurik, A. R., Verheul, I. and Wennekers, A. R. M. (Eds.), Entrepreneurship: Determinants and Policy in a European-US Comparison, Kluwer Academic Publishers, Boston/ Dordrecht.

Verplanken, B. and Holland, R. W. (2002), "Motivated decision making: Effects of activation and self-centrality of values on choices and behavior", Journal of Personality and Social Psychology, Vol. 82, pp. 434-447.

Wdowiak, M. A., Schwarz, E. J., Breitenecker, R. J. and Wright, R. W. (2007), "Linking the cultural capital of the entrepreneur and early performance of new ventures: A cross-country comparison", Journal for East European Management Studies, Vol. 17, No. 2, pp. 149-183.

Williams, R. M. (1968), "Values", in Sills, E. (Ed.) International encyclopedia of the social sciences, MacMillan, New York.

Zahra, S. A., Nielsen, A. P. and Bogner, W. C. (1999), "Corporate entrepreneurship, knowledge and competent development", Entrepreneurship Theory and Practice, Vol. 23, No. 3, pp. 169-189. 
Figure 1. Cultural value dimensions

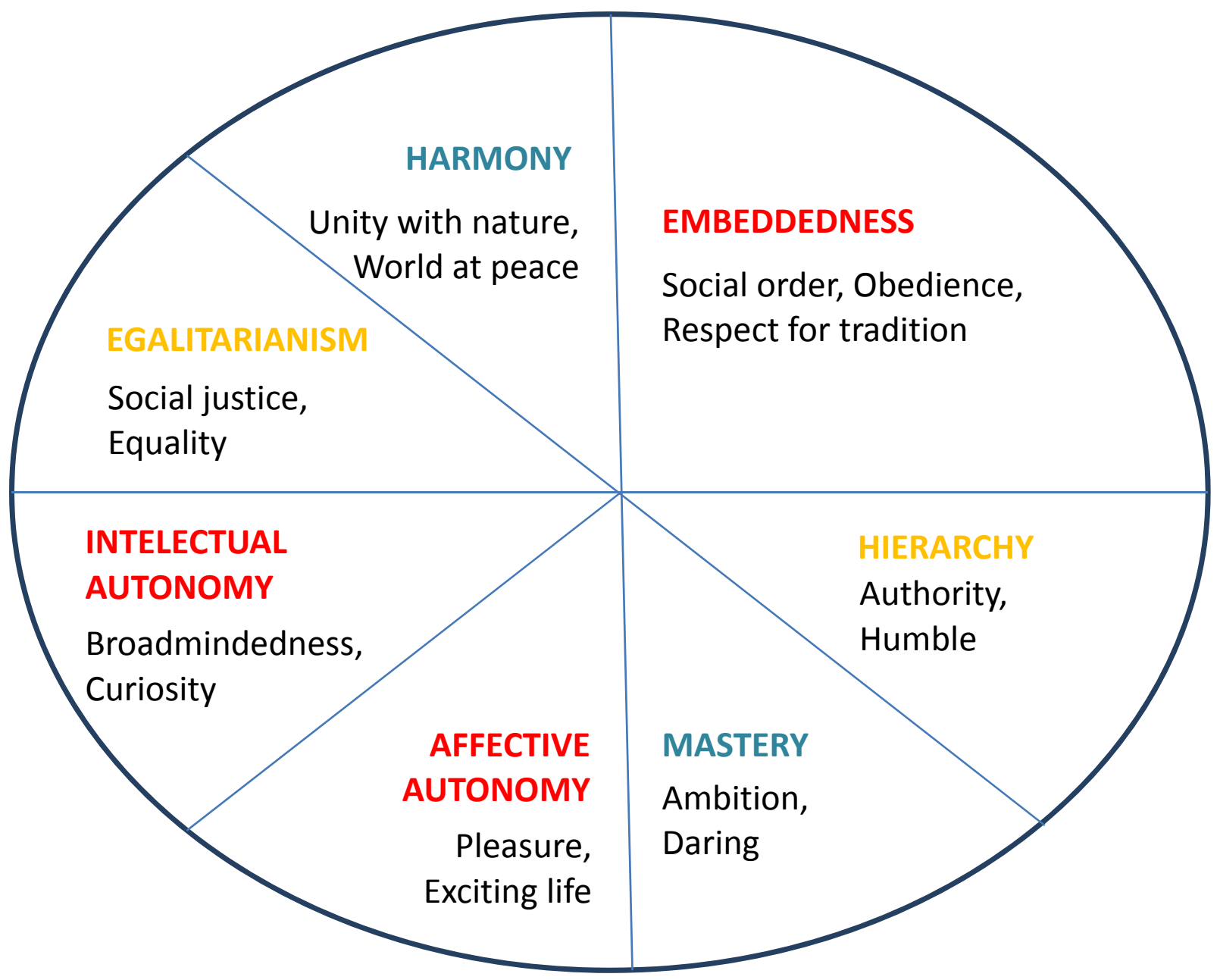

Source: Schwartz (2004), Figure 1, p. 89. 
Figure 2. Research model

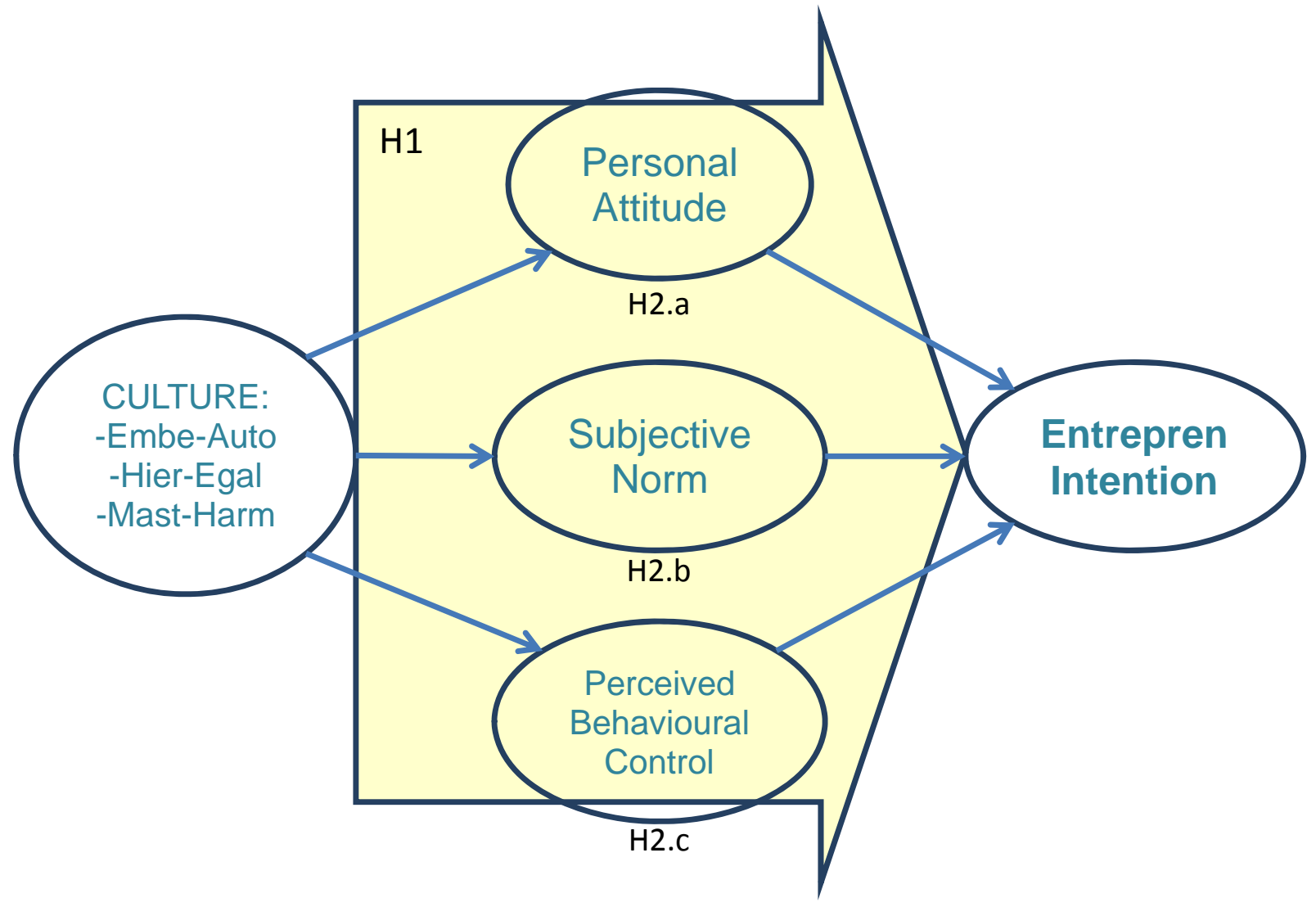


Figure 3. Culturally diverse regions in Spain

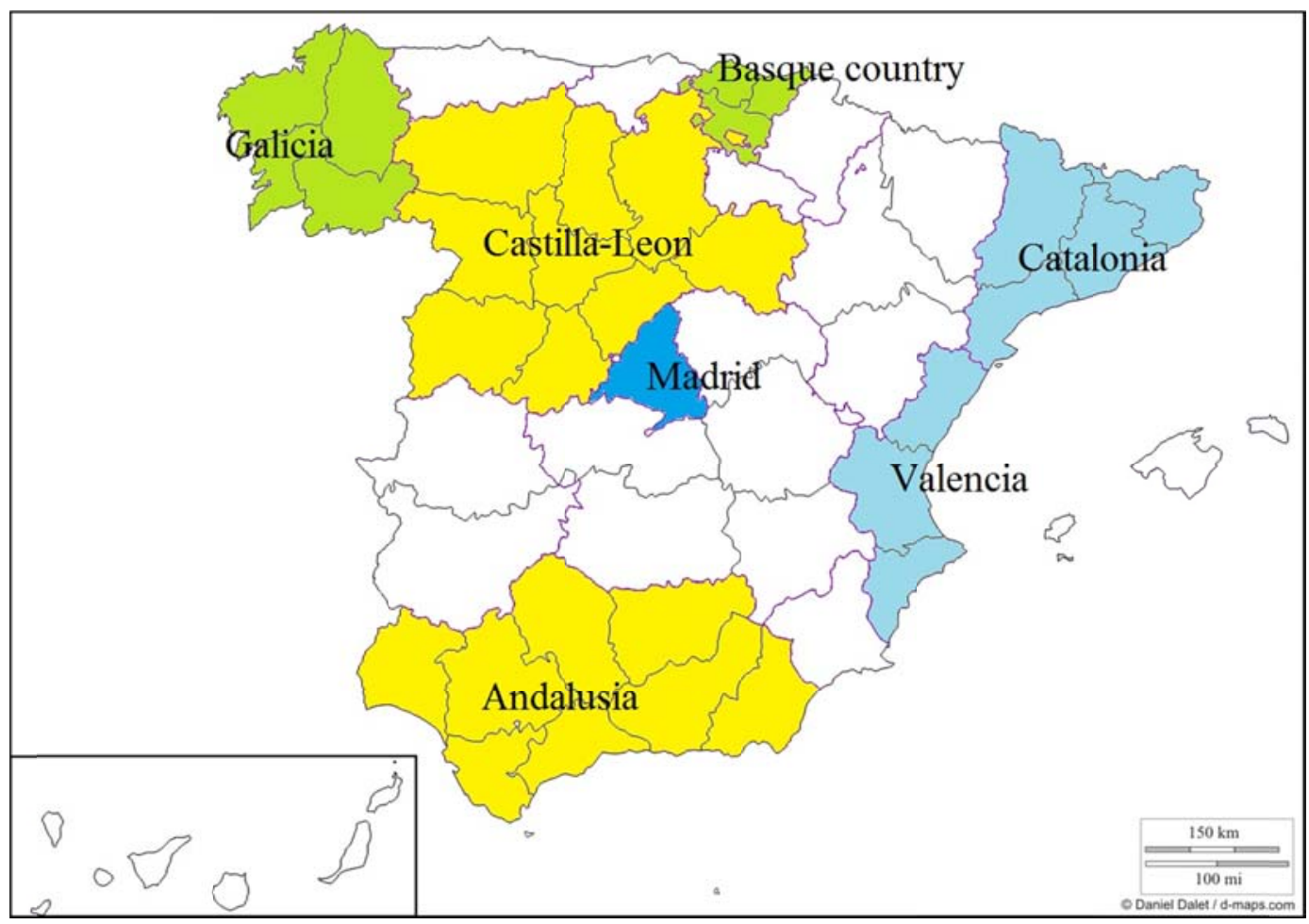


Table 1. Sample characteristics

\begin{tabular}{|c|c|c|c|c|c|c|c|}
\hline & Mean & $\begin{array}{l}\text { Std. } \\
\text { dev. }\end{array}$ & $\begin{array}{c}0 \\
(\%)\end{array}$ & $\begin{array}{c}1 \\
(\%)\end{array}$ & $\begin{array}{c}2 \\
(\%)\end{array}$ & $\begin{array}{c}3 \\
(\%)\end{array}$ & $\begin{array}{c}4 \\
(\%)\end{array}$ \\
\hline \multirow[t]{2}{*}{ Age } & 28.08 & 4.96 & & & & & \\
\hline & & & Female & Male & & & \\
\hline \multirow[t]{2}{*}{ Gender } & 0.43 & 0.48 & 57.5 & 42.5 & & & \\
\hline & & & No & Yes & & & \\
\hline Labour experience & 0.90 & 0.30 & 9.8 & 90.2 & & & \\
\hline $\begin{array}{l}\text { Self-employment } \\
\text { experience }\end{array}$ & 0.13 & 0.34 & 86.6 & 13.4 & & & \\
\hline \multirow[t]{2}{*}{ Family role model } & 0.62 & 0.49 & 37.9 & 62.1 & & & \\
\hline & & & Lower & $\begin{array}{l}\text { Lower- } \\
\text { middle }\end{array}$ & Middle & $\begin{array}{l}\text { Upper- } \\
\text { middle }\end{array}$ & Upper \\
\hline Socio-economic level & 1.89 & 0.65 & 2.6 & 19.1 & 65.1 & $\begin{array}{l}13.1 \\
\end{array}$ & 0.2 \\
\hline & & & $\begin{array}{l}\text { Priv. sect. } \\
\text { employee }\end{array}$ & $\begin{array}{l}\text { Pub. sect. } \\
\text { employee }\end{array}$ & $\begin{array}{c}\text { Self- } \\
\text { employed }\end{array}$ & \begin{tabular}{|c|}
$\begin{array}{c}\text { Un- } \\
\text { employed }\end{array}$ \\
\end{tabular} & Other \\
\hline Occupational status & -- & -- & 40.8 & 16.3 & 7.1 & 28.2 & 7.5 \\
\hline
\end{tabular}


Table 2. Cultural dimensions and Income in the Spanish regions

\begin{tabular}{lcccccc}
\multicolumn{1}{c}{ Region } & $\mathbf{N}$ & $\begin{array}{c}\text { Embeddedness } \\
\text { vs. Autonomy }\end{array}$ & $\begin{array}{c}\text { Hierarchy vs. } \\
\text { Egalitarianism }\end{array}$ & $\begin{array}{c}\text { Mastery vs. } \\
\text { Harmony }\end{array}$ & $\begin{array}{c}\text { GDP per } \\
\text { capita }\end{array}$ & $\begin{array}{c}\text { Entrepren. } \\
\text { Intention* }\end{array}$ \\
\hline Andalusia & 815 & .886 & 1.627 & .260 & $75.5 \%$ & $\mathbf{5 2 . 5 \%}$ \\
Castille-Leon & 492 & .845 & 1.642 & .290 & $99.6 \%$ & $43.2 \%$ \\
Catalonia & 176 & $\mathbf{1 . 0 0 7}$ & 1.665 & .283 & $\mathbf{1 1 7 . 3 \%}$ & $\mathbf{5 0 . 6 \%}$ \\
Valencia & 649 & $\mathbf{. 9 8 3}$ & 1.534 & .276 & $88.7 \%$ & $\mathbf{4 8 . 4 \%}$ \\
Galicia & 251 & .767 & $\mathbf{1 . 9 8 6}$ & $\mathbf{. 5 3 6}$ & $88.2 \%$ & $46.8 \%$ \\
Madrid & 340 & $\mathbf{1 . 0 2 5}$ & $\mathbf{1 . 7 3 4}$ & .294 & $\mathbf{1 2 9 . 9 \%}$ & $46.2 \%$ \\
Basque Country & 251 & .736 & $\mathbf{1 . 8 0 9}$ & $\mathbf{. 6 5 4}$ & $\mathbf{1 3 5 . 8 \%}$ & $42.5 \%$ \\
\hline Total & $\mathbf{2 9 7 4}$ & $\mathbf{. 9 0 1}$ & $\mathbf{1 . 6 6 9}$ & $\mathbf{. 3 3 0}$ & $\mathbf{1 0 0 . 0 \%}$ & $\mathbf{4 7 . 9 \%}$ \\
\hline
\end{tabular}

Note: Above-average figures are highlighted.

* Average intention level of respondents in each region. 
Table 3: Linear regression models on entrepreneurial intention

\begin{tabular}{|c|c|c|c|}
\hline Variables & $\begin{array}{c}\text { Model } 1 \\
\beta\end{array}$ & $\begin{array}{c}\text { Model } 2 \\
\beta\end{array}$ & $\begin{array}{c}\text { Model } 3 \\
\beta\end{array}$ \\
\hline Gender & $.161 * * *$ & $.157 * * *$ & $.110 * * *$ \\
\hline Labour Experience & .014 & .019 & .001 \\
\hline Self-Employment Exp. & $.214 * * *$ & $.213^{* * *}$ & $.153^{* * *}$ \\
\hline Family Role Model & $.086 * * *$ & $.076 * * *$ & $.029 *$ \\
\hline Embeddedness/Autonomy (centred) & --- & $.089 * *$ & .018 \\
\hline Hierarchy/Egalitarianism (centred) & --- & .011 & -.005 \\
\hline Mastery/Harmony (centred) & --- & .036 & -.049 \\
\hline GDP per capita (centred) & --- & $-.105 * * *$ & $-.036 \%$ \\
\hline Attitude to Entrepreneurship & --- & --- & $.203 * * *$ \\
\hline Subjective norm & --- & --- & $.135 * * *$ \\
\hline PBC & --- & --- & $.361 * * *$ \\
\hline $\begin{array}{r}R^{2} \\
\text { Adjusted } R^{2} \\
\Delta R^{2}\end{array}$ & $\begin{array}{c}.087 \\
.086 \\
.087 * * *\end{array}$ & $\begin{array}{c}.097 \\
.095 \\
.010 * * *\end{array}$ & $\begin{array}{c}.406 \\
.404 \\
.309 * * *\end{array}$ \\
\hline
\end{tabular}


Table 4: Linear regression models on intention antecedents

\begin{tabular}{|c|c|c|c|c|c|c|}
\hline \multirow[b]{3}{*}{ Explanatory Variables } & \multicolumn{6}{|c|}{ Dependent Variables } \\
\hline & \multicolumn{2}{|c|}{$\begin{array}{c}\text { Attitude to } \\
\text { entrepreneurship }\end{array}$} & \multicolumn{2}{|c|}{ Subjective norm } & \multicolumn{2}{|c|}{$\begin{array}{l}\text { Perceived Behavioural } \\
\text { Control }\end{array}$} \\
\hline & $\begin{array}{c}\text { Model A1 } \\
\beta\end{array}$ & $\begin{array}{c}\text { Model A2 } \\
\beta\end{array}$ & $\begin{array}{c}\text { Model S1 } \\
\beta\end{array}$ & $\begin{array}{c}\text { Model S2 } \\
\beta\end{array}$ & $\begin{array}{c}\text { Model P1 } \\
\beta\end{array}$ & $\begin{array}{c}\text { Model P2 } \\
\beta\end{array}$ \\
\hline Gender & $.034 \dagger$ & $.036^{*}$ & -.027 & -.025 & $.120 * * *$ & $.123 * * *$ \\
\hline Labour Experience & .012 & .007 & .017 & .014 & $.051 * *$ & $.045^{*}$ \\
\hline Self-Employment Exp. & $.108^{* * *}$ & $.101^{* * *}$ & .029 & .028 & $.107^{* * *}$ & $.102 * * *$ \\
\hline Family Role Model & $.062 * *$ & $.060 * *$ & $.093 * * *$ & $.091 * * *$ & $.056 * *$ & $.058 * *$ \\
\hline Socioeconomic level & $.044^{*}$ & $.047 *$ & $.045^{*}$ & $.048^{* *}$ & $.087 * * *$ & $.088^{* * *}$ \\
\hline Embedd/Auton (centred) & --- & $.142 * * *$ & --- & $.088 * *$ & --- & $.095 * *$ \\
\hline Hierar/Egalitar (centred) & --- & $.050 \dagger$ & --- & -.030 & --- & .024 \\
\hline Mast/Harmo (centred) & --- & $.141^{* *}$ & --- & $.110^{* *}$ & --- & $.119 * *$ \\
\hline GDP per capita (centred) & --- & $-.151^{* * *}$ & --- & $-.064 *$ & -- & $-.086 * *$ \\
\hline$R^{2}$ & .020 & .033 & .013 & .016 & .042 & .048 \\
\hline Adjusted $R^{2}$ & .018 & .030 & .011 & .013 & .041 & .045 \\
\hline$\Delta R^{2}$ & $.020 * * *$ & $.013^{* * *}$ & $.013^{* * *}$ & $.003^{*}$ & $.042 * * *$ & $.005^{* *}$ \\
\hline
\end{tabular}

$\dagger p<0.1, * p<0.05, * * p<0.01, * * * p<0.001$. 